waarschuwde dat zijn arbeidsovereenkomst zou worden beëindigd 'indien hij niet uiterlijk op 3 februari 2020 aan het verzoek zou voldoen'. Nadat volgens Jubiloto geen verbetering optrad, heeft zij op 29 februari 2020 de arbeidsovereenkomst met Ebecilio met onmiddellijke ingang beëindigd. Ebecilio heeft vervolgens een vordering ingesteld bij de DRC en schadevergoeding gevorderd wegens beëindiging zonder geldige reden.

De DRC beklemtoont dat alleen een inbreuk of een fout van een zekere ernst de beëindiging van een arbeidsovereenkomst rechtvaardigt. Met andere woorden, alleen wanneer er objectieve criteria zijn op grond waarvan redelijkerwijs niet kan worden verwacht dat de arbeidsverhouding tussen de partijen wordt voortgezet, kan een contract voortijdig worden beëindigd. Een voortijdige beëindiging van een arbeidsovereenkomst kan slechts een ultima ratio-maatregel zijn.

De DRC is van oordeel dat Jubiloto niet het bewijs heeft geleverd dat de houding van Ebecilio Jubiloto schade heeft berokkend. In het bijzonder merkt de DRC op dat de partijen slechts één maand voor de beëindiging van de arbeidsovereenkomst door Jubiloto eind februari 2020 deze overeenkomst hadden verlengd. Het feit dat Jubiloto de arbeidsovereenkomst heeft verlengd, is een duidelijke aanwijzing dat zij over het geheel genomen tevreden was over de prestaties van Ebecilio. Bovendien benadrukt de DRC dat er onvoldoende elementen in het dossier stonden om vast te stellen dat het alcoholgebruik van Ebecilio buiten de werkuren een negatieve invloed op zijn prestaties bij Jubiloto heeft gehad. Wat de aantijgingen van onbehoorlijk gedrag betreft, was er, naast twee schriftelijke waarschuwingen en de beëindigingsbrief, geen afdoende bewijs in het dossier om de aantijgingen van Jubiloto te staven dat Ebecilio de club in diskrediet heeft gebracht en onbehoorlijk of beledigend had gehandeld, ondanks verklaringen van clubfunctionarissen, die naar het oordeel van de DRC als subjectief moeten worden beschouwd.

De DRC concludeert dat zij het betoog van Jubiloto dat het gedrag van Ebecilio de orde van Jubiloto had verstoord op een wijze die schadelijk genoeg was om de onmiddellijke beëindiging van de arbeidsverhouding te rechtvaardigen, niet kan volgen. Bovendien is de DRC van oordeel dat de beëindiging van de arbeidsverhouding onevenredig en overhaast was, aangezien Jubiloto aan Ebecilio geen kans heeft gelaten om zich te rehabiliteren nadat hij de verantwoordelijkheid voor eventuele fouten had aanvaard en had verklaard dat hij bereid was om de arbeidsverhouding voort te zetten. Jubiloto had immers mildere maatregelen kunnen nemen om Ebecilio in staat te stellen te bewijzen dat hij zijn gedrag zou verbeteren en zijn contractuele verplichtingen jegens Jubiloto in de toekomst zal nakomen. De DRC concludeert dat de resterende waarde van de arbeidsovereenkomst vanaf de vroegtijdige beëindiging ervan door Jubiloto tot normale afloop EUR 1.336.363 bedraagt. $\mathrm{Na}$ de volledige en specifieke omstandigheden van deze zaak volledig te hebben onderzocht, beslist de DRC dat Jubiloto aan Ebecilio een schadevergoeding wegens contractbreuk van EUR 1.336.363 dient te beta- len, welk bedrag door de DRC als een redelijke en gerechtvaardigde schadevergoeding wordt beschouwd. Bovendien is $5 \%$ rente per jaar verschuldigd over voornoemd bedrag, vanaf de datum van de onderhavige beslissing.

NB. Er is een hoge drempel voor een club om tot onmiddellijke beëindiging van een arbeidsovereenkomst te mogen overgaan volgens de DRC. Een beëindiging van de arbeidsovereenkomst is al snel onevenredig en overhaast als de verwijten aan het adres van de speler onvoldoende kunnen worden gestaafd met bewijs en/of indien een speler niet eerst een kans heeft gekregen om zich te rehabiliteren. Een recente verlenging van de arbeidsovereenkomst zal het lastiger maken voor een club om aan te tonen dat er geldige redenen voor beëindiging zijn.

\section{VSZ 2021/11}

\section{DRC 29 september 2020, Georigi Kitanov (Georgi} Kitanov v. AFC Astra)

\section{Arbeidsovereenkomst van voetbalspeler mag op grond van Roemeens recht worden geschorst als gevolg van COVID-19.}

Op 5 mei 2020 heeft de Bulgaarse speler Georgi Kitanov (Kitanov) tegen zijn oud-werkgever, de Roemeense club AFC Astra (Astra), een vordering bij de DRC ingesteld. Hij vordert achterstallige salarisbetalingen, vermeerderd met rente. In zijn vordering wees Kitanov erop dat Astra zijn loon niet volledig zou hebben betaald, ook niet nadat zij in gebreke was gesteld. Astra weigerde nakoming van de arbeidsovereenkomst en betaling van het volledige salaris vanwege een 'noodverordening' die door de Roemeense autoriteiten op 16 maart 2020 was bekendgemaakt. Astra stelde dat zij de arbeidsovereenkomst en salarisbetalingen mocht schorsen en Kitanov recht zou hebben op slechts $75 \%$ van het Roemeense wettelijke basisinkomen dat door de staat Roemenië zou worden betaald. Volgens Kitanov was deze beslissing ongeldig en onwettig. Kitanov heeft uiteindelijk de arbeidsovereenkomst eenzijdig opgezegd op grond van art. 14bis RSTP omdat hij een totaalbedrag van meer dan drie maandelijkse salarissen van Astra tegoed zou hebben. Astra verzocht in de procedure om afwijzing van de vorderingen van Kitanov en voerde aan dat - in het licht van de uitbraak van COVID-19 - ook het Roemeense recht op de onderhavige zaak moest worden toegepast, aangezien laatstgenoemd recht meer gedetailleerde regels betreffende de sluiting, uitvoering en beëindiging van arbeidsovereenkomsten zou bevatten. Astra heeft voorts verklaard dat de schorsing van de arbeidsovereenkomst van Kitanov niet was gebaseerd op 'overmacht', maar op bepalingen van de Roemeense Arbeidswet. 
Vanwege het voorgaande wenst de DRC erop te wijzen dat de FIFA, in het licht van de wereldwijde COVID-19-uitbraak, een reeks richtsnoeren heeft uitgevaardigd, de COVID-19-richtsnoeren, die ertoe strekken passende richtsnoeren en aanbevelingen te verstrekken aan de aangesloten bonden en hun belanghebbenden, zowel om de gevolgen van de door COVID-19 veroorzaakte verstoringen te beperken als om ervoor te zorgen dat elke reactie in het gemeenschappelijk belang wordt geharmoniseerd. Bovendien heeft de FIFA de zogenoemde FIFA COVID-19 FAQ uitgebracht, waarin de meest relevante vragen in verband met de reglementaire gevolgen van de COVID-19uitbraak worden verduidelijkt en oplossingen worden aangedragen voor nieuwe regelgevingskwesties. Voorts stelt de DRC dat de voormelde COVID-19-documenten van de FIFA alleen van toepassing zijn op 'eenzijdige wijzigingen van bestaande arbeidsovereenkomsten'. De DRC is van oordeel dat het besluit van Astra om de arbeidsovereenkomst en de salarisbetalingen eenzijdig op te schorten moet worden beschouwd als een eenzijdige wijziging van de arbeidsverhouding tussen partijen. Het is duidelijk dat Astra het contract niet heeft beëindigd, maar slechts verschillende aspecten ervan, zoals de salarisbetaling, heeft gewijzigd. Als gevolg daarvan concludeert de DRC dat de FIFA COVID-19 Guidelines en de FIFA COVID-19 FAQ op de onderhavige zaak van toepassing zijn en de rechtmatigheid van de betrokken eenzijdige wijziging moet worden beoordeeld.

De DRC onderzoekt vervolgens of Astra al dan niet voldoende heeft aangetoond dat zij op basis van de 'noodverordening' die door de Roemeense autoriteiten is gepubliceerd en de Roemeense Arbeidswet, de arbeidsovereenkomst van Kitanov mocht schorsen en hem mocht verwijzen naar de betalingen die de staat Roemenië heeft verricht tijdens de vermeende noodtoestand die is uitgeroepen als gevolg van de COVID-19-pandemie. De DRC stelt vast dat Astra uitvoerig heeft uiteengezet hoe de schorsing van de arbeidsovereenkomst naar Roemeens recht zou zijn toegestaan op basis van de 'noodverordening' van de regering, waarnaar zij verwijst. Bovendien stelt de DRC vast dat er ten tijde van de schorsing van de arbeidsovereenkomst een alternatieve regeling voor inkomenssteun bestond, die voorzag in de betaling van een bepaald percentage van het salaris van Kitanov door de staat Roemenië. De DRC concludeert dat Astra derhalve heeft kunnen aantonen dat op basis van de Roemeense 'noodverordening' Astra de arbeidsovereenkomst van Kitanov tijdelijk mocht schorsen, en Kitanov daarbij mocht wijzen op de mogelijkheid om een deel van zijn salaris van de staat Roemenië te innen.

Vervolgens richt de DRC haar aandacht op de achterstallig salarisbetalingen die door Kitanov worden gevorderd. De DRC stelt vast dat deze vóór de schorsing van de arbeidsovereenkomst (gedeeltelijk) verschuldigd waren. De DRC wijst erop dat de (erkende) uitstaande salarisbetalingen, alsmede oudere schulden die nadien tijdens de schorsing van de arbeidsovereenkomst zijn vereffend, reeds vóór de schorsing van de arbeidsovereenkomst hadden moeten worden betaald. De DRC concludeert dat de uitbraak van COVID-19 niet mag worden gebruikt als een gelegenheid om te ontsnappen aan schulden die al in een eerder stadium opeisbaar waren geworden. Verder oordeelt de DRC dat Astra geen geldige rechtvaardigingsgrond heeft aangevoerd voor het niet betalen van de bedragen die onbetwist waren en openstonden op het tijdstip van de eenzijdige beëindiging van de arbeidsovereenkomst door Kitanov. Toen Kitanov de arbeidsovereenkomst beëindigde, waren meer dan twee salarisbetalingen verschuldigd, ondanks het feit dat Kitanov Astra 15 dagen had gegeven om het verzuim te herstellen. Hierdoor beslist de DRC dat Kitanov een gegronde reden had om de arbeidsverhouding eenzijdig te beëindigen op grond van art. 14bis RSTP. Astra dient aansprakelijk te worden gehouden voor de respectievelijke gevolgen.

NB. Een arbeidsovereenkomst en de verplichtingen die daaruit voortvloeien voor een voetbalclub kunnen (tijdelijk) worden geschorst als gevolg van COVID-19 indien dit naar nationaal recht is toegestaan. De uitbraak van COVID-19 mag echter niet gebruikt worden als een gelegenheid om te ontsnappen aan schulden die al in een eerder stadium opeisbaar waren geworden. 